\title{
A survey of the success of open innovation model application in Iran's knowledge base corporation (Case Study: Biotechnology Corporation)
}

\author{
Abbas Khamseh ${ }^{1 *}$, Reza Radfar², Ebrahim Moeiniªnd Hesam Madani \\ ${ }^{1}$ Ph.D. Candidate in Technology Management, Department of Technology Management, Science and Research Branch, Islamic \\ Azad University, Tehran, Iran. \\ ${ }^{2}$ Associate Professor in Industrial Management, Department of Technology Management, Science and Research Branch, Islamic \\ Azad University, Tehran, Iran. \\ ${ }^{3}$ Member of Board and Head of Group S\&T Policies, Iranian Research Organization for Science and Technology, Tehran, Iran. \\ ${ }^{4}$ Ph.D. Candidate in Technology Management, Department of Technology Management, Science and Research Branch, Islamic \\ Azad University, Tehran, Iran.
}

Khamseh1349@gmail.com¹ ,r.radfar@srbiau.ac.ir², emoeini@hotmail.com³, shmadani@gmail.com

\begin{abstract}
Biotechnology Corporations play a significant role in the economic and technologic development. As they have relatively similar features, problems and opportunities, a network system planning can create the related facilities and necessities for the purpose of innovation potentials developing and thriving. This study focuses on the determinative factors and their effects on the success of Open Innovation Model Application in Iran`s Biotechnology Knowledge Base.
\end{abstract}

Keywords: Innovation, Open Innovation, networking, Biotechnology Corporations, Iran

\section{Introduction}

Most past studies of Open Innovation focus mainly on the firm level of large corporation. But now, the landscape of innovation has changed enormously. Enterprises can no longer afford to innovate on their own, due to the labor mobility, abundant venture capitals and widely dispersed knowledge across multiple public and private organization. With increasing disintegration, outsourcing, modularization nowadays, the management of Open Innovation in the small companies is becoming more important (Shan Su\& Shang Wu \& Vanhaverbeke, 2010).

Successful innovation is a key to business growth. In the realm of technological development, innovation processes have been transformed into various forms, like open innovation, crowd sourcing innovation, or collaborative innovation.

Innovation, in general sense may be seen as a process of designing, developing and implementing a novel product or service to improve economic, physical and logical parameters in the process. Open innovation, on the other hand, incorporates joint efforts from in-house capabilities and possible outsourcing or combination of several input paths during the product or service development. However, innovation is not just any sort of change in an entity. It focuses on qualitative changes, and especially targeted to enhance knowledge gain that would lead to economic gain. It is not just adapting someone's novelties, but it creates something of its own as a new, at least not existed in exactly in such form before. Innovation may incorporate product specialization, or targeted commercialization, or an invention deliberately attempting to enhance the product value (Rahman \& Ramos, 2010).

Although evidence for open innovation practices has been provided for large MNEs, they have not yet been analyzed systematically for SMEs (Vrande et al., 2008).

Companies consider innovations as a major engine to enhance their performance and to strengthen their competitive position in the market. Many firms have paid most of their management attention to a greater focus on internal efficiencies of the development process, team structures, decision making and cross functional interaction. However, as more and more companies bring innovation straight to the heart of their corporate strategies, developing internal innovation capabilities is no longer sufficient to gain and sustain competitive advantage. Since innovation strategies look increasingly similar and commoditized, more and more organizations try to further improve their innovation performance through intensifying collaboration across industry networks and partnerships, opening up their innovation processes in line with the open innovation framework (Chesbrough 2003b, 2006a; EIRMA, 2004).

Prosper, grow and sustain a high profitability (Drucker, 1988; Christensen 1997; Thomke, 2001) all means that the questions that are asked in research no longer revolve around why innovation is important. The focus instead lies on how to innovate and how innovation processes can be managed. A recently proposed and popularized model for the management of innovation is based on the 
need for companies to open up their innovation processes and combine internally and externally developed technologies to create business value (Fredberg et al., 2008).

Most current economic growth is largely a result of small and medium sized enterprises (Siu, 2005; Nieto \& Santamaria, 2010). Since it is known that growing small businesses have a positive impact on the country's economic wellbeing through the creation of wealth and jobs, such growth also spurs further innovation (Carter \& Jones-Evans, 2006). Studies from developing countries show that innovation cooperation and interaction are becoming more and more important for SMEs to promote their innovation abilities (Biggs \& Shah, 2006; Liefner et al., 2006).

Traditionally, open innovation has been analyzed mainly within the context of large, multinational, technology firms (Chesbrough, 2003b). Although Chesbrough et al. (2006) argued that large firms could differ from small firms in their adoption of open innovation, only a small number of studies on open innovation within smaller firms exist. For instance, Henkel (2006) examines both small and large firms, but focuses only on companies that develop open source software. Lecocq \& Demil (2006) study the U.S. tabletop role-playing game industry, which is a highly fragmented industry with SMEs as the main players. Furthermore, Christensen et al. (2005) illustrated the role of small companies over the life cycle of the technology. They also show that firm size does influence the innovation strategy and value capturing ability of firms on new technology (Vrande et al., 2008).

By far, the small and medium enterprises (SMEs) who always deal with the clients at the grass roots the most and they have to satisfy the client base, though seldom they produce the product (Rahman \& Ramos, 2010).

Moreover, despite the globalization that offers unprecedented opportunities and challenges for SMEs, but seemingly they are thinking of mere survival in the context of global economy, marketing, value promotion, job creation and expansion (CSR Europe, 2008a, 2008b). Most of the SMEs communities are lagging behind promoting their products at the national level, and at the global level (OECD, 2006).

\section{Open innovation}

The notion of open innovation comes from Henry Chesbrough, a Berkeley professor at University of California that has gained international fame through his book "Open Innovation - The new imperative for Creating and Profiting from Technology" that appeared in 2003. He describes how companies in the 20th century have invested heavily in internal R\&D and hired the best people - enabling them to develop the most innovative ideas and protect them with IP strategies. The generated profit was used to reinvest in $R \& D$ - in a virtuous circle of innovation (Chesbrough, 2003a). However, at the end of the 20th century, a number of factors have changed, mainly: 1) Rise and increased mobility of knowledge workers, 2) Growing availability of venture capital. This has caused the closed innovation process in firms to start breaking up (Chesbrough, 2003a).

Chesbrough (2003b) identifies a number of factors indicating a shift in how innovation was managed: Useful knowledge has become widely diffused; Companies do not take full advantage of the wealth of information; Ideas that are not readily used can be lost; The value of an idea or a technology depend on its business model; The presence of VC changes the innovation process for everyone; Companies need to be active sellers and buyers of intellectual property (IP).

These insights led to the development of an open innovation model where firms commercialize external (as well as internal) ideas by deploying outside (as well as inside) pathways to the market - i.e. "the boundary between a firm and its surrounding environment is more porous, enabling innovation to move easily between the two" (Chesbrough, 2003a, p. 37). In an open innovation process, projects can be launched from internal or external sources and new technology can enter at various stages. Projects can also go to market in many ways, such as out-licensing or a spin-off venture in addition to traditional sales channels (Chesbrough, 2003b).

Open innovation is based on the following principles (Chesbrough, 2003a; 2003c): Not all smart people work in-house need to tap into external knowledge; External R\&D can generate significant value to us; Research does not need to originate from our internal work to be profitable for us; A strong business model is more important than first to market; Internal as well as external ideas are essential to win; We can capitalize on our own IP and we should buy others' IP when needed.

As a point of departure, Chesbrough argues that internal R\&D no longer is the invaluable strategic asset that it used to be due to a fundamental shift in how companies generate new ideas and brings them to the market (Chesbrough, 2003a,b). In the old model of closed innovation, firms relied on the assumption that innovation processes need to be controlled by the company - it was based on self-reliance. Changes in society and industry has led to an increased mobility of knowledge workers and the development of new financial structures such as venture capital - forces that have caused the boundaries of innovation processes to start breaking up (Chesbrough 2003a). Chesbrough (2006) defines open innovation as: "The use of purposive inflows and outflows of knowledge to accelerate internal innovation, and expand the markets for external use of innovation, respectively". Open Innovation is a paradigm that assumes that firms can and should use external ideas as well as internal ideas, and internal and external paths to market, as the 
firms look to advance their technology".

Open innovation has emerged as a model where firms commercialize both external and internal ideas/technologies and use both external and internal resources. In an open innovation process, projects can be launched from internal or external sources and new technology can enter at various stages. Projects can also go to market in many ways, such as out-licensing or a spin-off venture in addition to traditional sales channels (Chesbrough, 2003b).

There is a relative support for the development of Biotechnology in Iran`s private sectors. The important government supports that are considered as the most efficient ones are as follow: Granting loans (the most common support); Tax exemption; Buying lands according to the government price; Technical aids; Information aids.

\section{Materials and methods}

\subsection{Research Method}

Considering the fact that the results, which have been concluded from the above said research, can be used in the Biotechnology Corporations, the study is applied from the viewpoint of goal. It should be notified that the above said research is regarded as the survey study, according to its presence in different organizations and information acquisition from inside organization. The questionnaire has been applied for the purpose of information collection from experts. . Also ,the conceptual model of Research shown in Fig.1.

Fig.1. The conceptual model of research

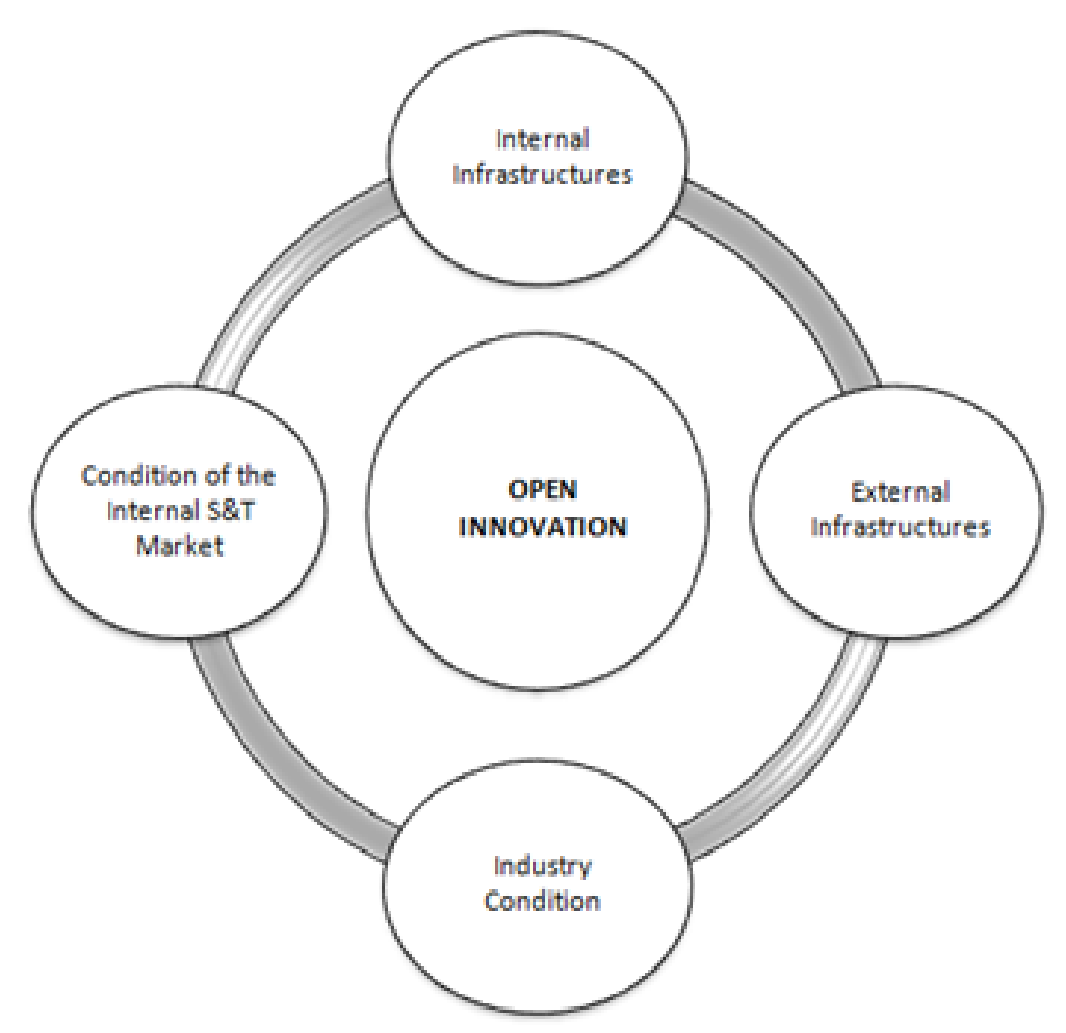

\subsection{Statistical Society}

The corporations and statistical society of this research are the managers, Biotechnology experts, and researchers of "SinaGene", "Pars Roos", "Ariogene", "Noavari Zisti Gouya", and "Behvazan" Biotechnology Corporation, as well as the "Pharmaceutical college of Tehran University", "Jami Research Center" and "Pastor Institute".

\subsection{Information analysis method:}

There are two methods which have been used for the analysis of research information. A: The statistical analysis; For analyzing the collected data with the application of questionnaire. B: The analysis which is based on the experts' judgment; For the purpose of questionnaire's validity, analysis of information in the questionnaires, drawing conclusions and presentation of solutions. 


\subsection{Research questions}

\subsubsection{Main Questions}

- What are the effective indicators in the success of Open Innovation Model Application in Iran`s Biotechnology Corporations?

- What is the total effect of the identified indicators on the success of Open Innovation Model Application in Iran`s Biotechnology Corporations?

\subsubsection{Secondary Questions}

- What is the indicator`s effect of Corporation`s Internal Infrastructure on the success of Open Innovation Model Application in Biotechnology Corporations?

- What is the indicator`s effect of Corporation`s External Infrastructure on the success of Open Innovation Model Application in Biotechnology Corporations?

- What is the indicator's effect of Conditions Governing the Industry on the success of Open Innovation Model Application in Biotechnology Corporations?

- What is the indicator`s effect of Conditions Governing the Internal S\&T Market on the success of Open Innovation Model Application in Biotechnology Corporations?

\subsection{Research hypothesis}

Total effect of the identified indicators on the success of Open Innovation Model Application by Iran`s Biotechnology Corporations is desirable.

\section{Results}

\subsection{Collecting the findings of research questions}

\subsubsection{Collecting the findings related to the first main question of the research:}

The main indicators have been extracted for identifying the effective indicators in the success of Open Innovation Model Application in Iran`s Biotechnology Corporations. It should be notified that the above said task has been carried out with the review of literature and conducting a survey. So the experts' ideas about the indicators` relation and their effectiveness have been collected. Finally, Indicators Tree of Open Innovation In Biotechnology Corporations, shown in Fig.2.

\subsubsection{Collecting the findings of the research secondary questions:}

The above said indicators have been applied in the questionnaire planning for collecting information in the secondary questions as well as the second main one. It should be added that a survey has been conducted and 50 experts' ideas were collected. They were experts in innovation and technology management.

A) Collecting the findings of the first secondary question which are about the effect of Corporation's Internal Infrastructure on the success of Open Innovation Model Application in Biotechnology Corporations (Table 1).

B) Collecting the findings of the second secondary question which are about the effect of Corporation`s External Infrastructure on the success of Open Innovation Model Application in Biotechnology Corporations (Table 2).

C) Collecting the findings of the third secondary question which are about the effect of Conditions governing the industry on the success of Open Innovation Model Application in Biotechnology Corporations (Table 3).

D) Collecting the findings of the forth secondary question which are about the effect of Conditions governing the Internal S\&T Market on the success of Open Innovation Model Application in Biotechnology Corporations (Table 4).

\subsubsection{Collecting the findings of the second main question of the research:}

Considering the collection of research secondary questions, the second question's answer, which was about the total effect of identified indicators on the success of Open Innovation Model Application by Biotechnology Corporations, was recognized and classified as can be seen in table 5. It should be notified that the effect of identified indicators usage in the application of Open Innovation Model was considered as \%68. Furthermore, each one of the main dimensions`effect on the success of Open Innovation Model Application has been shown the Table 5 . 
Fig.2. Indicators Tree of Open Innovation

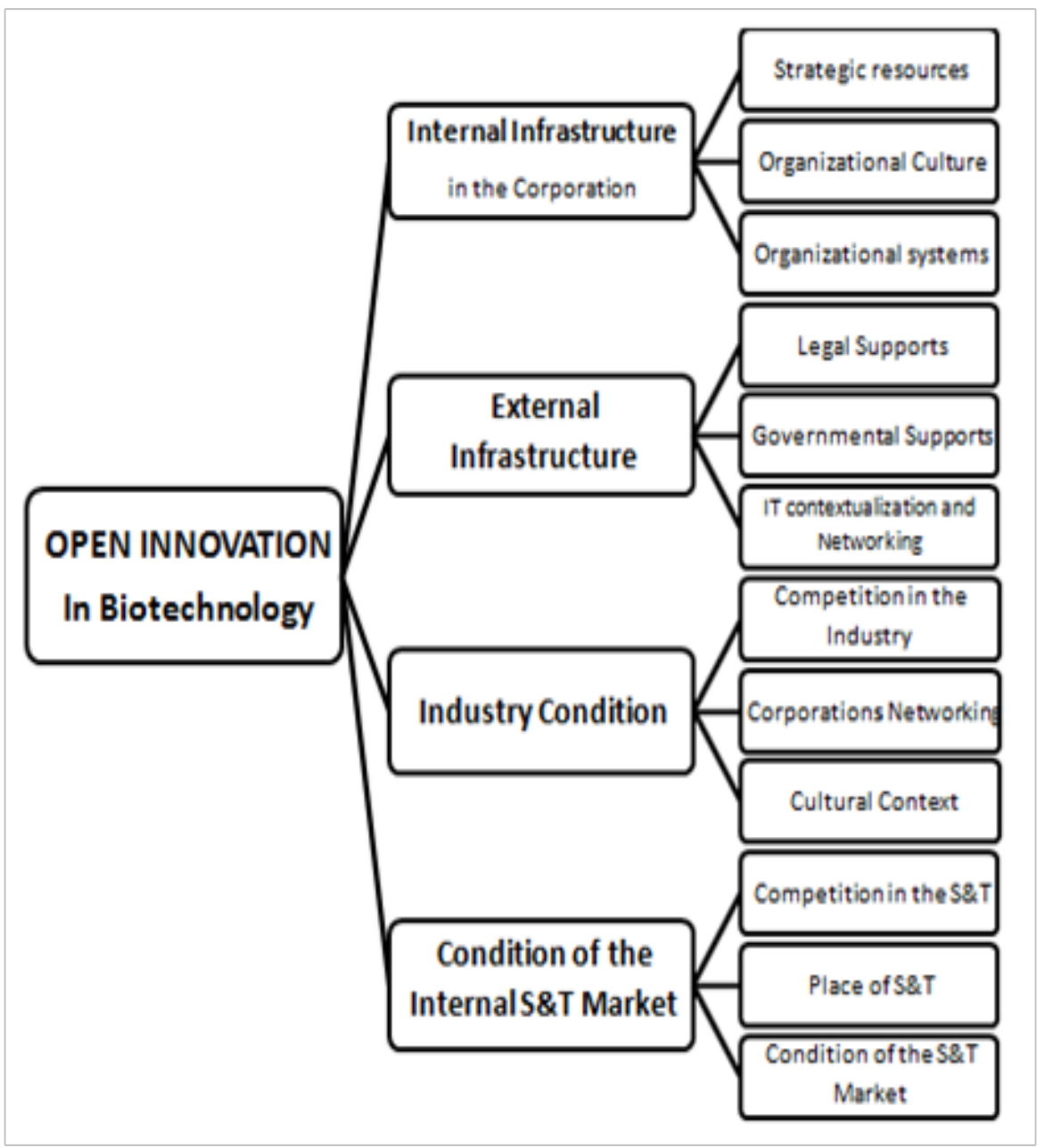

\subsection{Collecting the findings of research hypothesis}

Total effect of Internal Infrastructure in the Corporation, External Infrastructure in the Corporation, Conditions governing the industry and Conditions governing the Internal S\&T Market indicators on the success of Open Innovation Model Application by Iran`s Biotechnology Corporations is desirable.

\subsubsection{The main hypothesis:}

At least one of the effective indicators has not been accomplished successfully in the success of Open Innovation Model Application by Iran`s Biotechnology Corporations.

$$
H_{0}: \mu_{R} \neq 75 \%
$$

\subsubsection{The alternative hypothesis:}

All of the effective identified indicators have been accomplished successfully in the success of Open Innovation Model Application by Iran`s Biotechnology Corporations.

$H_{1}: \mu_{R}=75 \%$

The mean of the total effect of effective recognized indicators on the success of Open Innovation Model Application has been shown in the following table. According to Table 6, the estimated $t$ is -3.658 .

In order to make decision about whether the mean of the total effect of effective recognized indicators on the success of Open Innovation Model Application is in the suitable level or not, it is a need to compare the test significance level with the error level.

According to Table 7 and since the test significance level is far less than the error one (0.05) in the confidence level of $95 \%$ 
H0 hypothesis has been rejected; I.e. the mean of the total effect of effective recognized indicators is not 75 . Considering the fact that the estimated $t$ is negative and regarding the distribution of $t$, it can be concluded that the mean of the total effect of effective recognized indicators on the success of Open Innovation Model Application is far less than the acceptable standard level.

Table 1. Findings of the research first secondary question

\begin{tabular}{|c|c|c|c|}
\hline $\begin{array}{c}\text { Secondary } \\
\text { Dimensions }\end{array}$ & Indicators & \%Average & $\begin{array}{l}\text { \%Total } \\
\text { Average }\end{array}$ \\
\hline \multirow{7}{*}{ Strategic Resources } & Providing the suitable financial resources & 80.00 & \multirow{7}{*}{76.34} \\
\hline & Technologic capabilities & 83.55 & \\
\hline & Having access to the required informational resources & 79.52 & \\
\hline & Existence of the efficient leadership team & 88.06 & \\
\hline & $\begin{array}{l}\text { Having access to the part-time employees in the outside } \\
\text { and inside corporations }\end{array}$ & 59.03 & \\
\hline & $\begin{array}{l}\text { Having (Taking advantage of) the related technical experts } \\
\text { and multi-disciplinary ones }\end{array}$ & 67.90 & \\
\hline & Having a business model & 76.77 & \\
\hline \multirow{6}{*}{ Organizational Culture } & Participatory and team work culture & 69.68 & \multirow{6}{*}{67.12} \\
\hline & $\begin{array}{l}\text { Senior managers` risk taking in the application of open } \\
\text { innovation }\end{array}$ & 74.52 & \\
\hline & Having the organizational strategy and vision & 58.71 & \\
\hline & Culture of the application of internal and external R\&D & 77.10 & \\
\hline & $\begin{array}{l}\text { Working and membership culture in the context of open } \\
\text { innovation networks }\end{array}$ & 64.03 & \\
\hline & $\begin{array}{l}\text { Taking advantage of the universities` professors and con- } \\
\text { sultants }\end{array}$ & 58.71 & \\
\hline \multirow{4}{*}{ Organizational Systems } & Effective documentation system & 69.19 & \multirow{3}{*}{69.78} \\
\hline & Establishment of knowledge management system & 68.23 & \\
\hline & $\begin{array}{l}\text { Existence of organizational innovations and knowledge } \\
\text { protective systems }\end{array}$ & 71.94 & \\
\hline & \multicolumn{2}{|l|}{ Total Average } & $\% 71.68$ \\
\hline
\end{tabular}

\section{Discussion}

\subsection{Ranking for the effective indicators in the success of Open Innovation}

The effective identified indicators are prioritized according to Friedman variance analysis test.

The effective identified indicators are prioritized according to Friedman variance analysis test.

\subsubsection{The main hypothesis:}

The effective identified indicators rank is the same in the success of Open Innovation Model Application: $H_{0}$

\subsubsection{The alternative hypothesis:}

At least one of the effective indicators has the significance difference in the success of Open Innovation Model Application:

$H_{1}$

According to Table 8 and since the test significance level is far less than the error one in the confidence level of $95 \%$, H0 hypothesis has been rejected. In other words, the effective indicators in the success of Open Innovation Model Application have a significance difference with each other (H1). So the effective prioritizing of indicators in the success of Open Innovation Model Application has been shown in table 9 .

According to Table 9, and among all the other features of the research, effective indicators of the Internal Infrastructure and Conditions Governing the Internal S\&T Market have been located in the first and last place, respectively. It should be notified that the first indicator has the greatest average rank and the last one has the lowest average, consequently. So, Friedman test results show 
that among all the other effective indicators in the success of Open Innovation Model Application, effective indicators in the Internal Infrastructure are considered as the most important ones in Iran`s Biotechnology Corporations.

Table 2. Findings of the research second secondary question

\begin{tabular}{|c|c|c|c|}
\hline $\begin{array}{l}\text { Secondary } \\
\text { Dimensions }\end{array}$ & Indicators & $\%$ Average & $\begin{array}{l}\text { \%Total } \\
\text { Average }\end{array}$ \\
\hline \multirow[t]{4}{*}{ Legal supports } & Suitable legal supporting regulations for the Knowledge Base corporations & 85.81 & 72.10 \\
\hline & Supporting the establishment of private Knowledge Base corporations & 68.87 & \\
\hline & Existence of patent and intellectual property rights active centers & 73.87 & \\
\hline & $\begin{array}{l}\text { Legislation of Knowledge Base corporations' cooperation and membership in } \\
\text { the networks }\end{array}$ & 59.84 & \\
\hline \multirow[t]{3}{*}{ Governmental } & $\begin{array}{l}\text { Granting specific privileges to the partnership establishment among Knowledge } \\
\text { Base corporations for the implementation of projects }\end{array}$ & 60.48 & 62.10 \\
\hline & $\begin{array}{l}\text { Granting specific facilities to the corporations for the purpose of releasing } \\
\text { science and technological findings in the society }\end{array}$ & 57.42 & \\
\hline & $\begin{array}{l}\text { Granting subsides and investigational grants to the Knowledge Base } \\
\text { corporations enjoying open innovation model }\end{array}$ & 68.39 & \\
\hline \multirow{4}{*}{$\begin{array}{l}\text { Contextualization } \\
\text { of the Information } \\
\text { Technology and } \\
\text { Networking }\end{array}$} & $\begin{array}{l}\text { Application of information technology for the development of open innovation } \\
\text { networks }\end{array}$ & 64.52 & 62.26 \\
\hline & Existence of high-speed internet in the Knowledge Base corporations & 63.06 & \\
\hline & $\begin{array}{l}\text { Planning knowledge management system in accordance with the Knowledge } \\
\text { Base corporations networking structure }\end{array}$ & 59.19 & \\
\hline & \multicolumn{2}{|l|}{ Total Average Total Average } & $\% 66.15$ \\
\hline
\end{tabular}

\section{Conclusion}

Pierson Correlation Coefficient test has been applied in the relation determination which is among the variables of research hypothesis and recognition of the existent relation between the effective indicators in the success of Open Innovation Model Application.

Existent correlation between the effective indicators in the success of Open Innovation Model Application has been shown in Table 10.

- $\quad$ As can be observed in Table 10, the effective indicators in the Internal Infrastructures have correlation with the External Infrastructures and Conditions governing the internal S\&T market in the significance level of $(0.01)$. The above said correlations are $0.627,0.735$ and 0.476 , respectively.

- $\quad$ Furthermore, the effective indicators in the External Infrastructures have correlation with the effective indicators in the Internal Infrastructures and Conditions governing the internal S\&T market in the significance level of $(0.01)$. The above said correlations are about $0.627,0.787$ and 0.886 , respectively.

- The effective indicators in the Conditions governing the industry have correlation with the effective indicators in the Internal Infrastructures, External Infrastructures and Conditions governing the internal S\&T market in the significance level of $(0.01)$. The above said correlations are $0.735,0.787$ and 0.682 , respectively.

- $\quad$ The effective indicators in the Conditions governing the internal S\&T market have correlation with the effective indicators in the Internal Infrastructures, External Infrastructures and Conditions governing the industry in the significance level of $(0.01)$. The above said correlations are $0.476,0.886$ and 0.682 , respectively.

Lots of evidence introduces innovation as the main stimulant in the corporations`economic development and prosperity; I.e. research questions are no longer about innovation importance; the key point is how to innovate and manage the innovation processes.

Iran`s Biotechnology Corporations are run by the application of close innovation traditional approaches. The above said enterprises are not acquainted with the synergistic literature and its way by the application of open innovation. As a result they are 
quite vulnerable in the competitive market.

Table 3. Findings of the research third secondary question

\begin{tabular}{|c|c|c|c|}
\hline $\begin{array}{l}\text { Secondary } \\
\text { Dimensions }\end{array}$ & Indicators & \%Average & $\begin{array}{c}\text { \%Total } \\
\text { Average }\end{array}$ \\
\hline \multirow[t]{5}{*}{ Competition in } & $\begin{array}{l}\text { Existence of healthy competition and anti-trust regulations } \\
\text { between the present Knowledge Base corporations in the industry }\end{array}$ & 55.32 & 61.87 \\
\hline & $\begin{array}{l}\text { Justice in the sharing of privileges and stimulants in the public and } \\
\text { private Knowledge Base corporations }\end{array}$ & 63.55 & \\
\hline & $\begin{array}{l}\text { Opening up equal opportunities for the public and private } \\
\text { Knowledge Base corporations }\end{array}$ & 62.42 & \\
\hline & $\begin{array}{l}\text { Existence of suitable supply network for the Knowledge Base } \\
\text { corporations in each industry }\end{array}$ & 62.58 & \\
\hline & $\begin{array}{l}\text { Existence of the suitable market and society of the potential and } \\
\text { de facto customers }\end{array}$ & 65.48 & \\
\hline \multirow[t]{5}{*}{ Corporations` } & $\begin{array}{l}\text { Creating suitable infrastructure for the purpose of present } \\
\text { corporations`networking in the industry }\end{array}$ & 62.90 & 63.45 \\
\hline & $\begin{array}{l}\text { Existence of science and technological networks leading centers } \\
\text { toward the open innovation in each industry }\end{array}$ & 55.97 & \\
\hline & $\begin{array}{l}\text { Specifying the regulations of corporations joining and separation } \\
\text { from the cooperation networks }\end{array}$ & 59.68 & \\
\hline & $\begin{array}{l}\text { Assurance from the security and rights of innovations and } \\
\text { inventions' sharing in the networks }\end{array}$ & 73.55 & \\
\hline & $\begin{array}{l}\text { Network formation among Knowledge Base corporations of an } \\
\text { industry, universities and suppliers }\end{array}$ & 65.16 & \\
\hline \multirow[t]{5}{*}{ Suitable } & $\begin{array}{l}\text { Existence of interaction and networking culture among different } \\
\text { industries` Knowledge Base corporations }\end{array}$ & 55.81 & 68.23 \\
\hline & $\begin{array}{l}\text { Existence of incentives and facilities for the purpose of shifting } \\
\text { from close innovation to the open one in the industries }\end{array}$ & 68.87 & \\
\hline & $\begin{array}{l}\text { Existence of investment culture in the common infrastructures for } \\
\text { the purpose of trimming costs }\end{array}$ & 77.10 & \\
\hline & $\begin{array}{l}\text { Existing the culture of taking advantage of common expert } \\
\text { employees among Knowledge Base corporations }\end{array}$ & 71.13 & \\
\hline & \multicolumn{2}{|l|}{ Total Average } & $\% 64.25$ \\
\hline
\end{tabular}

The research results indicate that the infrastructure indicators of Internal Infrastructure are of great importance for joining Iran`s Biotechnology Corporations to the open innovation field.

The government supports pave the way for ever-increasing establishment and registration of knowledge base corporations in various fields. On the other hand, some positive measures have been implemented in the field of registration and legal supports of innovations and establishment of networking among the existent Biotechnology Corporations in the science and technology parks. Furthermore, the application of domestic technologic products and encouraging people to use them is a top priority. The above said measures develop the science and technology market.

\subsubsection{In spite of the government supports, there are some problems in the application of Biotechnology in the corpora- tions. The most important ones are as follow:}

- $\quad$ Most of the Biotechnology Corporations, especially the startup ones, are not able to pay heavy bails for the guarantee of their loans and as a result they avoid borrowing. Not to mention, the existent administrative bureaucracy is the other reason. 
Table 4. Findings of the research forth secondary question

\begin{tabular}{|c|c|c|c|}
\hline Secondary Dimensions & Indicators & \%Average & $\begin{array}{c}\text { \%Total } \\
\text { Average } \\
\end{array}$ \\
\hline \multirow{5}{*}{$\begin{array}{l}\text { Competition in the } \\
\text { Technology }\end{array}$} & $\begin{array}{l}\text { Existence of the suitable technological market for various } \\
\text { activities of Knowledge Base corporations }\end{array}$ & 75.00 & 70.77 \\
\hline & $\begin{array}{l}\text { Aligning of the Knowledge Base corporations`activities } \\
\text { with the customers`needs }\end{array}$ & 69.19 & \\
\hline & Specific support of the technological leading corporations & 71.94 & \\
\hline & $\begin{array}{l}\text { Existence of new markets` potential for technological } \\
\text { products of the Knowledge Base corporations }\end{array}$ & 65.97 & \\
\hline & $\begin{array}{l}\text { The possibility of exporting technological and science } \\
\text { products of the Knowledge Base corporations }\end{array}$ & 71.77 & \\
\hline \multirow{4}{*}{$\begin{array}{l}\text { Science and Technology } \\
\text { Place }\end{array}$} & $\begin{array}{l}\text { The status of knowledge-based employees in the society } \\
\text { and the appropriate welfare in accordance with their status }\end{array}$ & 68.55 & 68.27 \\
\hline & The place of science and technology in the society & 60.48 & \\
\hline & $\begin{array}{l}\text { Existence of venture capitalists for supporting corporations } \\
\text { science and technological activities }\end{array}$ & 73.39 & \\
\hline & $\begin{array}{l}\text { Existence of science and technology commercialization } \\
\text { centers }\end{array}$ & 70.65 & \\
\hline \multirow{6}{*}{$\begin{array}{l}\text { Condition of the Science } \\
\text { and Technology Market }\end{array}$} & $\begin{array}{l}\text { Development of the domestic technology market because } \\
\text { of sanctions }\end{array}$ & 61.77 & 67.42 \\
\hline & $\begin{array}{l}\text { Productions amount of science and high-tech in } \\
\text { accordance with the society need }\end{array}$ & 69.03 & \\
\hline & $\begin{array}{l}\text { Market support of the science and technological } \\
\text { production in comparison with the technology transferring }\end{array}$ & 67.58 & \\
\hline & Market support of the local and domestic technologies & 69.03 & \\
\hline & $\begin{array}{l}\text { Customers risk taking in the application of Knowledge Base } \\
\text { corporations' innovations }\end{array}$ & 69.68 & \\
\hline & \multicolumn{2}{|l|}{ Total Average Total Average } & $\% 68.86$ \\
\hline
\end{tabular}

Table 5. Total effect of dimensions on the success of Open Innovation application by Iran 's Biotechnology Corporations

\begin{tabular}{|l|l|}
\hline \hline Dimensions Main & $\%$ Average \\
\hline \hline Internal Infrastructure & 71.68 \\
\hline External Infrastructure & 66.15 \\
\hline Conditions governing the industry & 64.25 \\
\hline $\begin{array}{l}\text { Conditions governing the Internal S\&T } \\
\text { Market }\end{array}$ & 68.86 \\
\hline Total Average & $\% 68$ \\
\hline
\end{tabular}


Table 6. The single sample t test results for the total effect of effective recognized indicators on the success of Open Innovation

\begin{tabular}{||l||l||l||l|l||}
\hline Variable & subject & Mean & $\begin{array}{l}\text { Standard } \\
\text { deviation }\end{array}$ & $\begin{array}{l}\text { Standard } \\
\text { Error Mean }\end{array}$ \\
\hline $\begin{array}{l}\text { Total effect of } \\
\text { the effective } \\
\text { recognized } \\
\text { indicators }\end{array}$ & 31 & 67.433 & 11.519 & 2.069 \\
\hline
\end{tabular}

Table 7. The single sample t test results for the total effect of effective recognized indicators on the success of Open Innovation

\begin{tabular}{||l|l|l|l|l|l|l|}
\hline \hline Test result & Test Value=75 & \multicolumn{5}{|c|}{ Variable } \\
\hline \hline \multirow{3}{*}{ Rejection of H0 } & $\begin{array}{l}\text { Error Level of } \\
0.05\end{array}$ & $\begin{array}{l}\text { Mean } \\
\text { Difference }\end{array}$ & $\begin{array}{l}\text { Significance } \\
\text { Level }\end{array}$ & $\begin{array}{l}\text { Degree of } \\
\text { Freedom }\end{array}$ & The estimated t & $\begin{array}{l}\text { Total effect of the } \\
\text { effective recognized } \\
\text { indicators }\end{array}$ \\
\cline { 2 - 7 } & Lower & Upper & -7.567 & 0.001 & 30 & -3.658 \\
\cline { 2 - 3 } & -11.793 & -3.342 & & & & \\
\hline
\end{tabular}

Table 8. Friedman test results of the effective indicators in the success of Open Innovation Model Application.

\begin{tabular}{|l|l||l|l|l|l||}
\hline $\begin{array}{l}\text { Number of } \\
\text { sample }\end{array}$ & $\begin{array}{l}\text { Estimated } \\
\text { K2 }\end{array}$ & $\begin{array}{l}\text { Degree of } \\
\text { Freedom }\end{array}$ & Significance Level & Error Level & Test Results \\
\hline \hline 31 & 24.311 & 3 & 0.000 & 0.05 & Rejection of H0 \\
\hline
\end{tabular}

Table 9. Friedman ranking for the effective indicators in the success of Open Innovation Model Application

\begin{tabular}{|l|l|l|l|}
\hline Row & Variables & Average rank & $\begin{array}{l}\text { Variables' } \\
\text { ranking }\end{array}$ \\
\hline \hline 1 & Internal Infrastructure & 3.15 & First \\
\hline 2 & $\begin{array}{l}\text { Conditions governing the } \\
\text { Internal S\&T Market }\end{array}$ & 2.92 & Second \\
\hline 3 & External Infrastructure & 2.19 & Third \\
\hline 4 & $\begin{array}{l}\text { Conditions governing the } \\
\text { industry }\end{array}$ & 1.74 & Forth \\
\hline
\end{tabular}

- $\quad$ Although in most cases, the market of Biotechnology products in these corporations is considered as the public one, and the government can take advantage of the above said force to support the private sector, the studies indicate that there is not any systematic plan for the application of such forces. So according to some corporations, it is considered as the weak one. In some cases there is no management in supporting the startup Biotechnology corporations.

- Apparently, there are some regulations which have been set about the tax exemption and financial support of Biotechnology Private Corporations. However, lots of private sectors do not know anything about such rules and their applications i.e. there is no comprehensive plan that can help Biotechnology Corporations to know the existent rules and regulations in the specialized field.

- Standardization of the related Biotechnology products is considered as one of the other government supports, which brings about some problems. There are some products that have been produced but there are no systematic quality control and standardiza- 
tion mechanism in the country. The above said problems bring about delays in the product's commercialization. In some cases, such delays make the competing products to be marketed earlier.

Table 10. Existent correlation between the effective indicators in the success of Open Innovation Model Application

\begin{tabular}{|l|l||l|l||l||l||}
\hline \hline & $\begin{array}{l}\text { Internal } \\
\text { Infrastructures }\end{array}$ & $\begin{array}{l}\text { External } \\
\text { Infrastructures }\end{array}$ & $\begin{array}{l}\text { Conditions } \\
\text { governing } \\
\text { industry }\end{array}$ & $\begin{array}{l}\text { Conditions } \\
\text { governing } \\
\text { lnternal }\end{array}$ S\&T Market & \\
\hline \hline \multirow{2}{*}{ Internal Infrastructures } & Correlation & 1.000 & 0.627 & 0.735 & 0.476 \\
\cline { 2 - 6 } & Significance level & - & 0.000 & 0.000 & 0.007 \\
\hline \multirow{2}{*}{ External Infrastructures } & Correlation & 0.627 & 1.000 & 0.787 & 0.886 \\
\cline { 2 - 6 } & Significance level & 0.000 & - & 0.000 & 0.000 \\
\hline \multirow{2}{*}{$\begin{array}{l}\text { Conditions governing the } \\
\text { industry }\end{array}$} & Correlation & 0.735 & 0.787 & 1.000 & 0.682 \\
\cline { 2 - 6 } & Significance level & 0.000 & 0.000 & - & 0.000 \\
\hline $\begin{array}{l}\text { Conditions governing the } \\
\text { Internal S\&T Market }\end{array}$ & Correlation & 0.476 & 0.886 & 0.682 & 1.000 \\
\hline & Significance level & 0.007 & 0.000 & 0.000 & - \\
\hline
\end{tabular}

Absence or shortage of the supportive structures in the Biotechnology context wastes a lot of time in the private sector of Biotechnology. We can mention Incubator, Technology Park and industrial cluster as the examples of such structures. It should be notified that some measures have been implemented for the creation of Incubator and Park which are still a few and startups.

In recent years the efforts of government in the establishment of science and technology parks and other incubators all over the country, establishment of Biotechnology Corporations over there, granting subsides will motivate Biotechnology Corporations to join the open innovation field and accelerate the process.

\section{References}

1 Chesbrough HW (2003a) The era of open innovation. MIT Sloan Manage. Rev. 44(3), 35-41.

2 - Chesbrough HW (2003b) Open innovation: the new imperative for creating and profiting from technology. Boston, MA: Harvard Business School Press.

3. Chesbrough HW (2003c) The logic of open innovation: Managing intellectual property. California Manage. Rev. 45(3), 33-58.

4 Chesbrough HW (2006a) Open business models: How to thrive in a new innovation landscape. Harvard Business School Press: Boston, MA.

5• Chesbrough HW (2006b) New puzzles and new findings. In: Open innovation: Researching a new paradigm: Chesbrough HW \& Vanhaverbeke W \& West J (Eds.), pp:15-33. Oxford: Oxford University Press.

6• Christensen CM (1997) The innovator's dilemma, Harvard Business Review Press, Boston, US.

7 CSR Europe (2008a) The European Alliance for CSR Progress Review 2007: Making Europe a pole of excellence on CSR. European Commission, Brussels, 4 March 2008.

8• CSR Europe (2008b) R\&D Open innovation: Networks with SME. Open Innovation Network, 6 November 2008.

90 Drucker PF (1988) The coming of the new organization, Harvard Bus. Rev. 66(1), 45-53.

10• EIRMA (2004) Technology Access for open innovation. Working Group Report WG63, Eirma: Paris.

11 Fredberg Tobias, Elmquist Maria and Ollila Susanne (2008) Managing open innovation - Present findings and future directions. Chalmers University of Technology, VINNOVA Report VR 2008:02.

12- OECD (2006) The Athens action plans for removing barriers to SME access to international markets. Adopted at the OECDAPEC Global Conference in Athens, on 8 November 2006, OECD Report, Paris.

13. Rahman Hakikur and Ramos Isabel (2010) Open Innovation in SMEs: From closed boundaries to networked paradigm, Uni- 
versity of Minho, Guimaraes, Braga, Portugal, Issues in Informing Science and Information Technology, Volume 7, 2010.

14- Shan Su Yu, Shang Wu Feng and Vanhaverbeke Wim (2010) How small firms can benefit from open innovations? Evidence from Taiwanese Biotechnology Firms. Opening up innovation: strategy, organization and technology. at Imperial College London Business School, June 16 - 18, 2010.

15- Thomke S (2001) Enlightened experimentation - the new imperative for innovation. Harvard Bus. Rev. 79(2), 66-75.

16• Vrande Jong and Vanhaverbeke Rochemont (2008) Open innovation in SMEs: Trends, motives and management challenges. Scientific Analysis of Entrepreneurship and SMEs, Netherlands Ministry of Economic Affairs. 